\title{
Glycoconjugates and keratin 18 define subsets of taste cells
}

\author{
Q. ZENG, A. LAWTON and B. OAKLEY* \\ Department of Biology, University of Michigan, Ann Arbor, MI 48109, USA
}

Received 17 January 1995 and in revised form 5 July 1995

\begin{abstract}
Summary
Sections of neonatal, normal adult and denervated adult rat tongue were examined with lectin histochemistry. Attention was focused upon intragemmal cells (cells within the taste bud) and the surrounding perigemmal cells. Informative staining patterns were observed with fout of 12 lectins: Ulex europaeus (UEA-I), Bauhinia purpurea (BPA), Helix pomatia (HPA) and Lotus tetragonolobus (LTA) agglutinins. In normal adult tongues, BPA bound to those lingual epithelial cells lacking contact with the basal lamina. After they formed, vallate taste buds were laterally surrounded by distinctive BPA-positive cells. HPA reacted selectively with $28 \%$ and LTA with $23 \%$ of the intragemmal cells in vallate/foliate taste buds. In double-stained taste buds there was a statistically significant overlap of LTA-positive cells and keratin 18-positive cells. The overlap between HPA binding and keratin 18 was more marked: double-stained cells comprized $67 \%$ of all stained cells. During taste bud development in neonates keratin 18 synthesis preceded HPA binding. In contrast, during the replacement of adult taste cells, keratin 18 synthesis and HPA binding were generally concurrent. Keratin 18 and HPA probably identify the same subset of older taste receptor cells. HPA may bind to glycoconjugates on the surface of keratin 18-positive cells. In denervated adult tongue the loss of all UEA-I-positive or BPA-positive perigemmal cells suggests that perigemmal as well as intragemmal cells are nerve-dependent.
\end{abstract}

\section{Introduction}

Glycoconjugates of animal tissues have heterogeneous molecular structures and multiple functions. Lectins provide a means of visualizing glycoconjugate distributional patterns in tissue sections. Although lectins often bind extensively to epithelial cells, the more selective staining with some lectins can serve to identify different cells and stages of cell differentiation (Brabec et al., 1980; Brown et al., 1987; Shimizu et al., 1991; Suter et al., 1991; Gargiulo et al., 1993; Neogrady et al., 1994; Takami et al., 1994). Histological patterns of lectin binding in gustatory tissues have been examined in catfish and frog (Witt \& Reutter, 1988) rabbit (Witt \& Miller, 1992) and hamster (Ohmura et al., 1989). Glycoconjugates specific to rat vallate taste cells have been detected with monoclonal antibodies against carbohydrates (Dodd \& Jessell, 1985; Akabas et al., 1988; Smith et al., 1993; 1994).

Shape and location help distinguish three types of taste bud cells. Basal cells are polygonal cells on the

* To whom correspondence should be addressed. basolateral margins of taste buds. Intragemmal cells are fusiform or elongated cells comprizing the taste bud interior. Perigemmal cells are moderately elongated cells on the lateral margins of taste buds. Our initial objective was to identify lectins that would react selectively with taste cells and perhaps distinguish among these three classes of taste cells.

We screened 12 lectins on rat tongue sections. Helix pomatia (HPA) and Lotus tetragonolobus (LTA) agglutinins selectively bound to subsets of intragemmal cells. Ulex europaeus (UEA-I) and Bauhinia purpurea (BPA) lectins gave more general, but informative, staining patterns in the gustatory epithelium. We analysed the staining patterns of these four lectins not only in adult rat tongues but also during development and after denervation. We linked the present work to our recent and ongoing studies of keratins in taste buds in which we found that while most, if not all, intragemmal vallate cells had keratins 7, 8, 19 and 20 , only $26 \%$ of the intragemmal cells were immunopositive for keratin 18 (Knapp et al., 1995; Zhang et al., 1995). Therefore, in the present research we used double staining to compare the subset of keratin 
18-positive intragemmal cells with the subsets of HPA-positive and LTA-positive intragemmal cells. Recent observations that keratins are glycosylated (Chou et al., 1992), and that lectins can bind directly to keratin peptide sequences (Shikhman et al., 1994), suggested that a lectin might be found with selective binding to keratin 18-positive cells.

\section{Materials and methods}

\section{Tissue preparation}

Fifteen Sprague-Dawley albino rats (Harlan Sprague Dawley, Indianapolis, IN) weighing 220-300 g were anaesthetized with sodium pentobarbital $(100 \mathrm{mg} / \mathrm{kg}$ body weight) and perfused intracardially with heparinized Ringer's solution followed by $4 \%$ paraformaldehyde or acid-alcohol (70\% ethanol and $10 \%$ acetic acid). Nine neonatal rats were euthanized by $\mathrm{CO}_{2}$ gas. Cryostat sections 8-10 $\mu \mathrm{m}$ thick were mounted on gelatin-coated slides.

Four rats were used to study the effects on lectin binding of unilateral transection of the IXth and chorda tympani nerve supply to the foliate and fungiform papillae. Anaesthesia was induced with a mixture of xylazine (Rompun) at $5 \mathrm{mg} / \mathrm{kg}$ body weight and ketamine- $\mathrm{HCl}$ at $125 \mathrm{mg} / \mathrm{kg}$ body weight. The operation did not impair feeding or drinking. The rats were euthanized after 15 or 21 days as described above, and the tongue tissue prepared for histological staining.

\section{Lectin histology}

Table 1 shows the 12 lectins screened, the concentrations employed and inhibitory sugars. Staining with eight of 12 lectins was not selective for taste buds. Here we report on lectins BPA, HPA and UEA-I used at a concentration of 4 $\mu \mathrm{g} \mathrm{ml}^{-1}$, and LTA at $10 \mu \mathrm{g} \mathrm{ml}^{-1}$. To block non-specific staining, mounted tissue sections were incubated with $0.5 \%$ bovine serum albumin in $0.1 \mathrm{M}$ phosphate-buffered saline (PBS), $\mathrm{pH}$ 7.4. This and each of the subsequent steps were followed by rinsing the sections in PBS. Sections were incubated for $60 \mathrm{~min}$ with a biotinylated lectin followed by an avidin-biotin-peroxidase complex (ABC, Vector) for 30 $\mathrm{min}$. The sections were developed in a mixture of $3^{\prime}-3^{\prime}$-diaminobenzidine $\left(0.5 \mathrm{mg} \mathrm{ml}^{-1}\right), 0.01 \% \mathrm{H}_{2} \mathrm{O}_{2}$ and $0.04 \%$ nickel chloride. Sections were viewed under the microscope to control for the intensity of staining. All histological procedures were carried out at room temperature. As controls, the omission of lectin from the staining protocol eliminated staining as did pre-incubation of each lectin with an appropriate inhibitory sugar (see Table 1). Lectins and sugars were purchased from E-Y Laboratories, San Mateo, California, (BPA, HPA and LTA) or SigmaChemical Co., St. Louis, Missouri.

\section{Double staining}

Three 4-min rinses with PBS preceded and followed each of the following steps. Mounted tongue sections were incubated for $1 \mathrm{~h}$ with biotinylated HPA or biotinylated LTA followed by $1.5 \mu \mathrm{g} \mathrm{ml}^{-1}$ Strepavidin-Texas Red (GIBCO $B R L)$ for $30 \mathrm{~min}$. After treatment with normal goat serum (3\% NGS in 0.1 M PBS/Triton X-100, pH 7.4; Cappel, Organon Teknika) for $30 \mathrm{~min}$, the tissue was incubated for $1 \mathrm{~h}$ with the primary monoclonal antibody against keratin 18 (MAb LE65, Amersham), followed by treatment with 40 $\mu \mathrm{g} \mathrm{ml}{ }^{-1}$ fluorescein isothiocyanate (FITC)-conjugated anti-mouse IgG (Sigma) for $45 \mathrm{~min}$. All reactions were carried out at room temperature. The slides were rinsed in PBS, dehydrated in a graded series of ethanol $(70 \%, 95 \%$, $2 \times 100 \%, 1$ min each), and mounted with DPX (BDH Ltd, Poole, England). In control experiments it was observed that omission of either biotinylated lectin or of Strepavidin-Texas Red eliminated staining. Similarly there was no staining if MAb LE65 or the FITC secondary antibody were omitted. Sections were visualized with fluorescence microscopy. To avoid counting the same cell twice, nonadjacent sections through the centre of taste buds were

Table 1. Lectins, concentrations and corresponding inhibitory sugars

\begin{tabular}{llcl}
\hline Abbreviation & $\begin{array}{l}\text { Lectin } \\
\text { source }\end{array}$ & $\begin{array}{l}\text { Concentration } \\
\left(\mu g l^{-1}\right)\end{array}$ & $\begin{array}{l}\text { Inhibitory } \\
\text { sugar }\end{array}$ \\
\hline BPA & Bauhinia purpurea & 4 & $\alpha, \beta$-GalNAc \\
HPA & Helix pomatia & 4 & $\alpha$-GalNAc \\
LTA & Lotus tetragonolobus & 10 & $\alpha$-L-Fucose \\
UEA-I & Ulex europaeus & 4 & $\alpha$-L-Fucose \\
Isolectin B4 & Bandeiraea simplicifolia & $4-20$ & $\alpha$-Gal \\
Con A & Canavalia ensiformis & $4-10$ & $\alpha$-Mannose \\
DBA & Dolichos biflorus & $4-20$ & $\alpha$-GalNAc \\
PHA-P & Phaseolus vulgaris & $4-20$ & Oligosaccharides \\
PNA & Arachis hypogaea & $4-20$ & $\beta$-Gal \\
PWA & Phytolacca americana & $4-20$ & $\beta$-GlcNAc \\
SBA & Glycine max & $4-20$ & $\alpha$-GalNAc \\
WGA & Triticum vulgaris & $4-20$ & $\beta$-GlcNAc, $\alpha$-NeuAc \\
\hline
\end{tabular}

Gal, galactose; GalNAc, $N$-acetylgalactosamine; GlcNAc, $N$-acetylglucosamine; NeuAc, neuraminic acid. 
examined. Technical difficulties prevented double staining with LTA and HPA.

\section{BrdU labelling}

Eight adult rats were injected intraperitoneally with 5bromo-2'-deoxyuridine (BrdU at $6.25 \mathrm{mg} / \mathrm{rat}$, Sigma), and sacrificed at daily intervals. After denaturation of DNA with $2 \mathrm{~N} \mathrm{HCl}$ the tissue underwent immunocytochemical staining. Incubation with anti-BrdU antibody (1:20, Accurate Chem. \& Sci. Corp) for $60 \mathrm{~min}$ was followed by the secondary antibody, biotin-sp-conjugated goat anti-rat IgG (1:1000, Jackson ImmunoResearch Lab.). The BrdU was visualized with the $A B C / 3^{\prime}-3^{\prime}$-diaminobenzidine sequence. After $4 \times 4 \mathrm{~min}$ rinses with PBS, the sections were subjected to the lectin histochemistry described above, except that $3^{\prime}-3^{\prime}$-diaminobenzidine was used without the nickel chloride solution. This made the HPA- or LTA-labelled cells yellow/brown, while the BrdU-labelled nuclei were blue. Omission of either BrdU injection, or the primary or secondary antibodies, eliminated staining.

\section{Results}

\section{Adult rat tongue}

Eight lectins reacted with most lingual epithelial cells, including the cells of taste buds (Isolectin B4, Con A, DBA, PHA-P, PNA, PWA, SBA and WGA, as listed in Table 1). These lectins were not examined further. Detailed analysis was carried out with four additional lectins; two that selectively bound to subsets of taste cells (LTA and HPA), and two that gave more widespread staining (UEA-I and BPA). Omission of the lectin eliminated staining (for example, Fig. 1C).
UEA-I staining. Of the four lectins evaluated in this report, UEA-I led to the most general staining. Staining with UEA-I was intense for the ordinary lingual epithelium, the gustatory papillae and the taste buds (Fig. 1). With UEA-I staining, the taste buds appeared wider than taste buds stained for keratins 7,8 or 19 (Wong et al., 1994; Knapp et al., 1995). Taste buds appeared wider because they encompassed the perigemmal cells and basal cells stained with UEA-I, but unstained by antibodies against keratins 7,8 , or 19. The UEA-I staining pattern was unaffected by changing the fixative from $4 \%$ paraformaldehyde to acid-alcohol.

$B P A$ staining. BPA reacted intensely with most suprabasal cells of the lingual epithelium including cells at the boundaries of fungiform, foliate and vallate taste buds. However, in contrast to UEA-I, BPA did not stain intragemmal cells or basal cells, either in the ordinary epithelium or in the gustatory epithelium (Figs 1,2). Acid-alcohol fixation prevented most staining.

LTA staining. The only intensely LTA-positive cells in the lingual epithelium were intragemmal cells. Few of these were in fungiform taste buds; most were a subset of vallate and foliate taste cells (Fig. 3). Scattered clusters of salivary gland cells also stained with LTA (not shown).

HPA staining. HPA markedly stained suprabasal cells of the anterior lingual epithelium, including perigemmal cells in the fungiform papillae. Occasional polygonal cells in fungiform taste buds were HPA-positive. HPA reacted intensely with about one quarter of
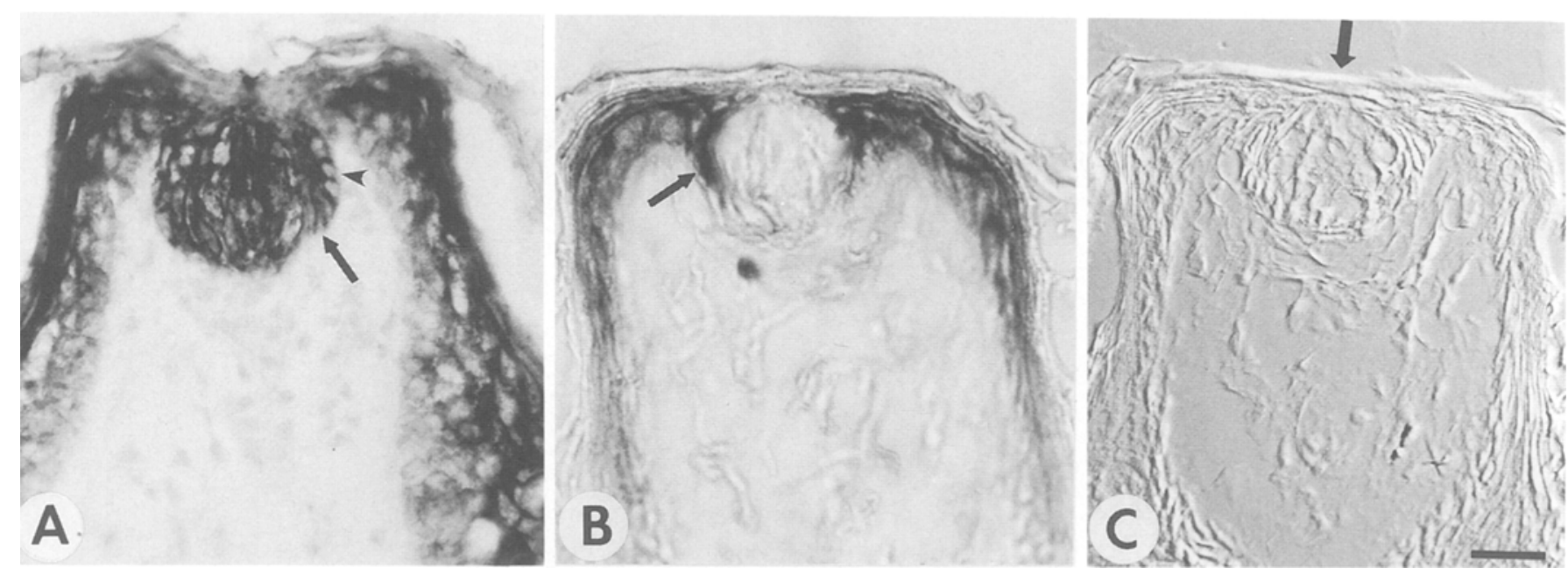

Fig. 1. UEA-I and BPA staining of fungiform papillae. (A) UEA-I reacted with all epithelial cells of the fungiform papilla. These included the intragemmal cells, the perigemmal cells (arrow) and the neighbouring basal cells (arrowhead). (B) BPA reacted with suprabasal cells and perigemmal cells (arrow) but not with basal cells or intragemmal cells. (C) There was no staining when lectin was omitted (Hoffman modulation contrast optics). Arrow indicates the taste pore. The scale bar is 20 $\mu \mathrm{m}$ for (A)-(C). 
foliate and vallate elongated taste cells (Fig. 3). No other epithelial cells in the posterior portion of the tongue were reactive at the HPA concentrations employed. Scattered clusters of salivary gland cells also stained with HPA.

Double staining: HPA-keratin 18. Most keratin 18positive intragemmal cells were also HPA-positive (Fig. 4A-C). Quantitative counts of stained intragemmal cells from three replications are provided in Table 2. Of the 1019 stained cells, $67 \%$ were double labelled for keratin 18 and HPA. Since keratin 18 is present in $26 \%$ of all vallate/foliate intragemmal cells (Zhang et al., 1995), we could calculate that the 815 keratin 18-positive cells observed were drawn from a surveyed population of 3135 intragemmal cells. Expressing the counts in Table 2 as a percentage of the 3135 intragemmal cells surveyed reveals that $22 \%$ of all intragemmal cells were double labelled, while $4 \%$ were keratin 18-positive only and $6.5 \%$ were HPApositive only. Chance overlap predicts that $7 \%$ of all intragemmal cells, not $22 \%$, should have been double stained. (The proportion of all cells that are keratin 18-positive $\times$ the proportion of all cells that were HPA-positive $=0.26 \times 0.28=0.07$ or $7 \%$ expected double staining vs $22 \%$ observed.) The higher than expected incidence of double staining is statistically significant $(p<0.001$, chi square.)

Double staining: LTA-keratin 18 . Forty per cent of stained intragemmal cells were double stained for keratin 18 and LTA (Table 2D). From the 26\% incidence of keratin 18-positive intragemmal cells we calculate that a sample of 2190 intragemmal cells was surveyed in sections double stained for LTA and keratin 18. As with keratin 18 and HPA, about twothirds of these surveyed intragemmal cells were unstained. When counts of stained cells were expressed as a percentage of all surveyed intragemmal cells, $14 \%$ were double labeled, $12 \%$ were keratin 18-positive only, and 9\% were LTA-positive only. The 14\% observed incidence of double-stained cells is statistically significant. (The proportion of all cells that are keratin 18-positive $\times$ the proportion of all cells that were LTA-positive $=0.26 \times 0.23=0.06=6 \%$ expected vs $14 \%$ observed; $p<0.001$, chi square.)
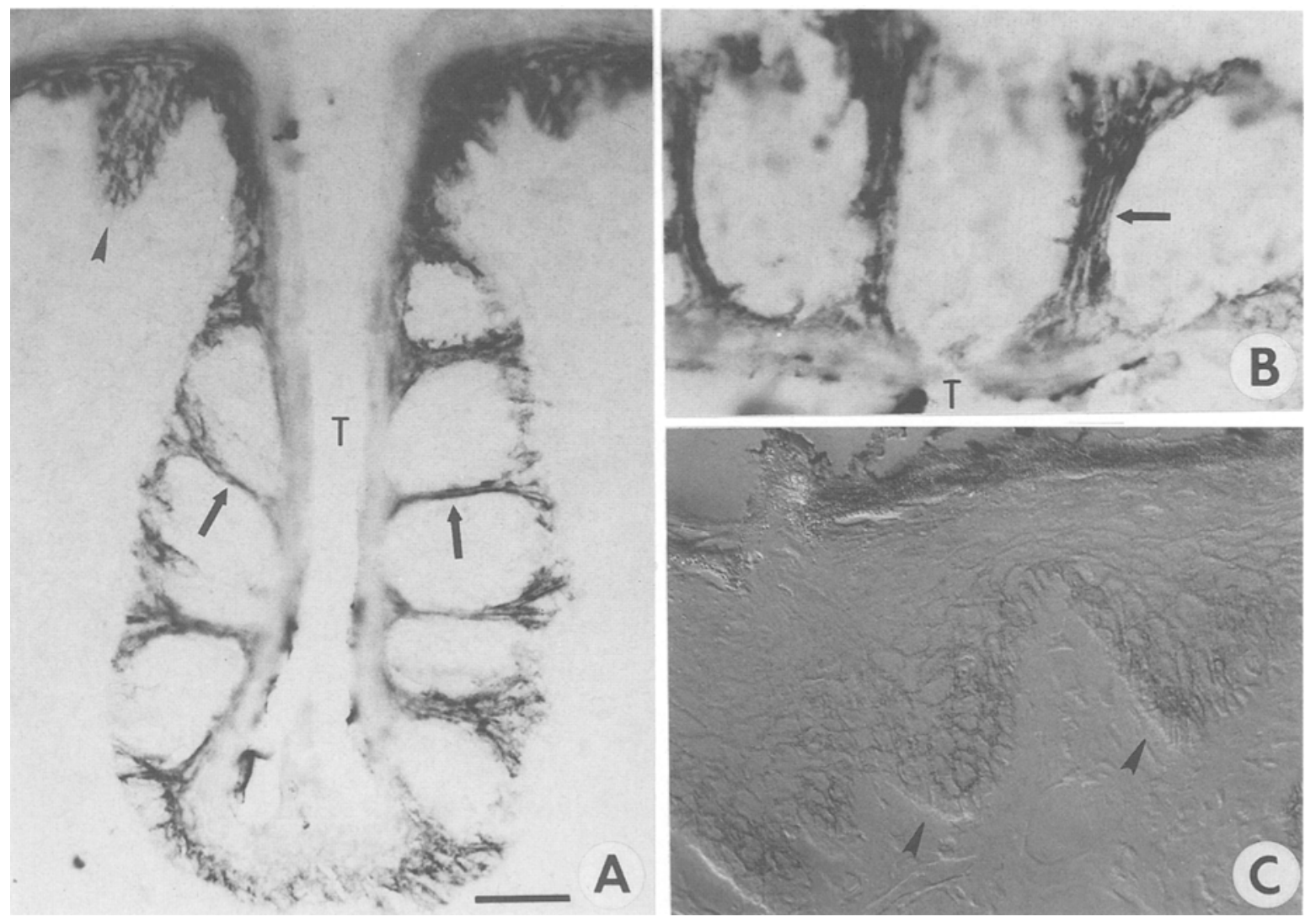

Fig. 2. BPA staining of foliate papillae. (A) The taste buds in the foliate trench were separated by BPA-positive boundaries (arrows). $T=$ foliate trench. (B) Higher magnification showed that the boundaries were composed of parallel, compressed cells (arrow). (C) At lower BPA concentrations, staining in ordinary lingual epithelium was most pronounced at the margins of cells. Basal cells were not stained with BPA (arrowheads in A and C). Hoffman modulation contrast. The scale bar in (A) is $30 \mu \mathrm{m}$ for (A) and (C) and $15 \mu \mathrm{m}$ for (B). 


\section{BrdU labelling of replacement cells in adults}

BrdU-positive intragemmal cells were first observed 1 day after BrdU injection. The HPA-positive cells present at this time were always BrdU-negative. Intragemmal cells double stained for HPA and BrdU were first observed 3 days after BrdU injection (Fig. $4 \mathrm{D}, \mathrm{E})$.

\section{Development of lectin reactivity}

We examined lectin staining in the vallate papilla on postnatal days 0,3 and 6 , when there are 0,17 and 35 mature vallate taste buds, respectively (Hosley \& Oakley, 1987). Initially widespread in the vallate papilla (P0-P3), LTA staining became restricted to taste cells by P6. In contrast, at P0 and P3 there was no staining with either HPA or BPA. By P6 staining of the vallate papilla resembled the adult pattern: BPA reacted generally with suprabasal cells, while intragemmal cells were selectively positive with LTA, HPA and for keratin 18 (Fig. 5).

\section{Partial denervation of adult rat tongue}

UEA-I staining of fungiform perigemmal cells and foliate taste buds was eliminated (data not shown). BPA-negative, horizontal squamous cells replaced the long vertical strands of cells comprising the BPA-

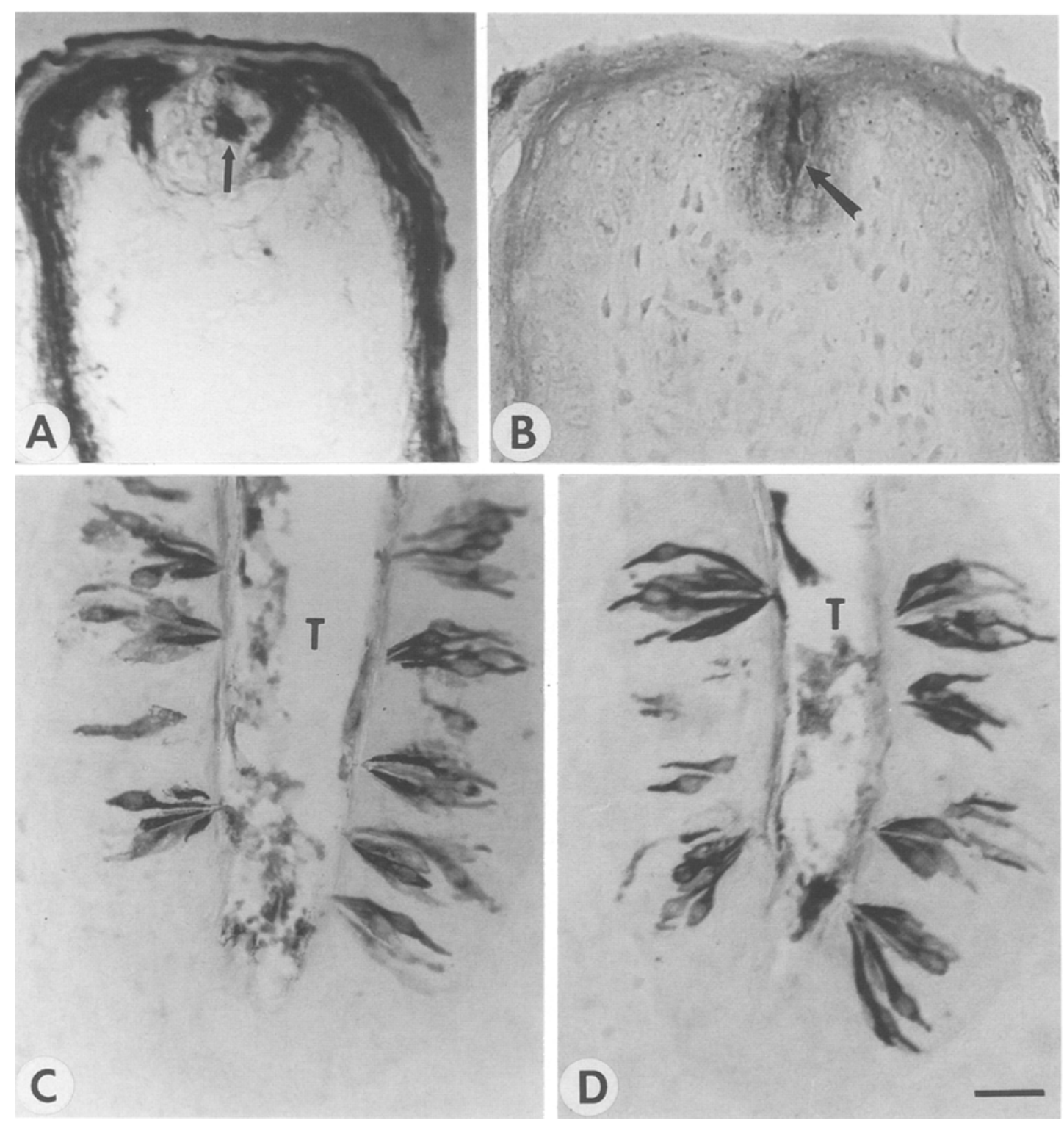

Fig. 3. HPA and LTA. (A) In fungiform papillae HPA stained suprabasal cells including perigemmal cells. An occasional non-elongated cell was stained within the fungiform taste bud (arrow). (B) LTA stained an occasional elongated cell in fungiform taste buds (arrow). In the posterior portion of the tongue, staining was restricted to subsets of elongated intragemmal cells for both (C) HPA and (D) LTA. Some debris in the vallate trench (T) was stained. The scale bar is $20 \mu \mathrm{m}$ for (A)-(D). 


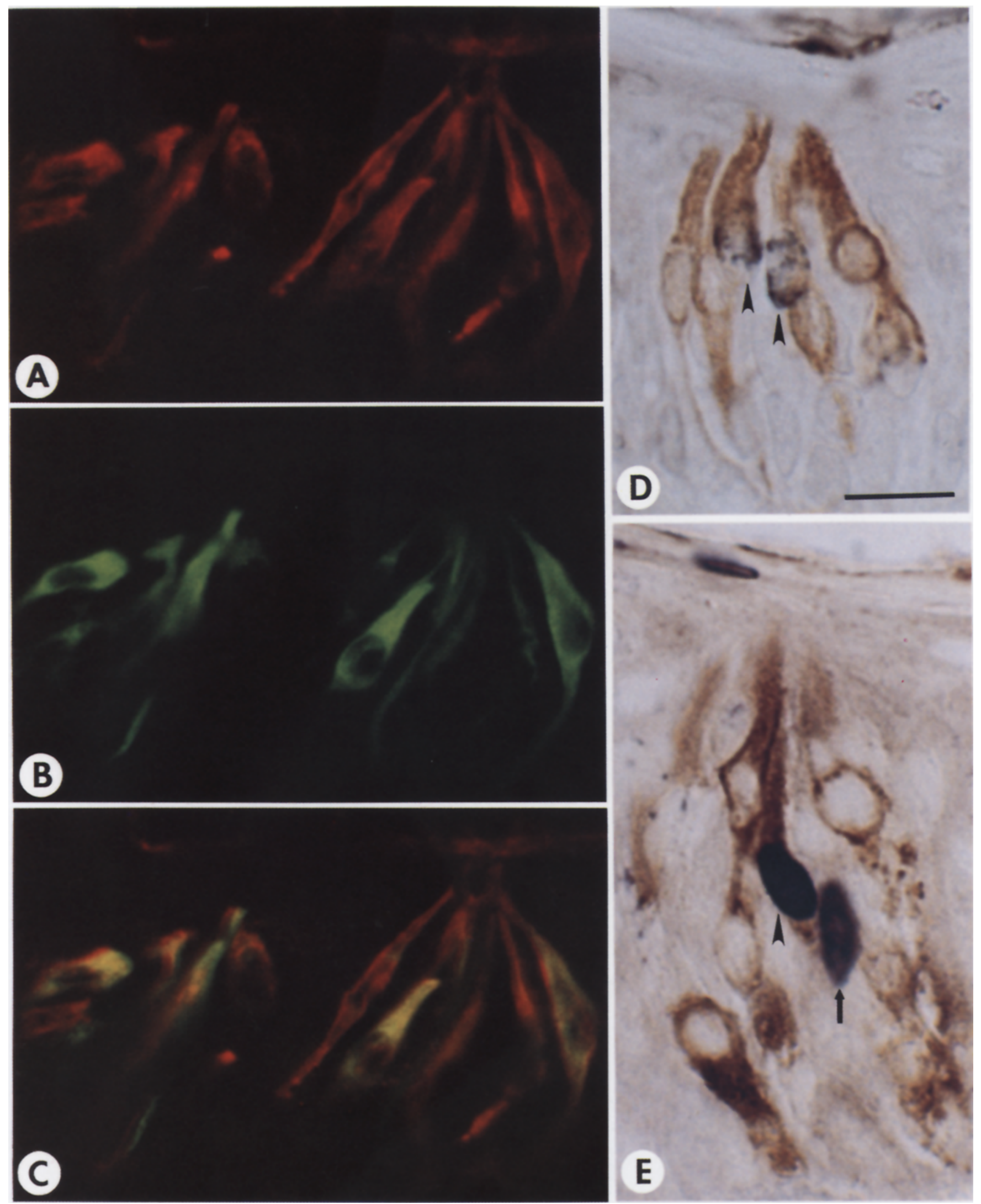

Fig. 4. A section through two vallate taste buds was: (A) photographed for HPA reactivity (Texas red); (B) photographed for keratin 18 (FITC, green); and (C) double exposed. Most keratin 18-positive cells were also HPA-positive. (D) Four days after BrdU injection two intragemmal cells were double stained for HPA and BrdU (arrowheads). (E) Three days after BrdU injection a cell was stained for BrdU only (arrow) while an adjacent cell was double stained for HPA and BrdU (arrowhead). Scale bar in (D) is $20 \mu \mathrm{m}$ for (A)-(D) and $16 \mu \mathrm{m}$ for (E). 
Table 2. Percentage of intragemmal cells positive for HPA and/or keratin 18 and for LTA and/or keratin 18

\begin{tabular}{lcc}
\hline Staining & $\begin{array}{l}\text { Number of cells } \\
\text { stained }\end{array}$ & Percentage \\
\hline HPA only & 204 & 20 \\
K18 only & 130 & 13 \\
HPA and K18 & 685 & 67 \\
Total & 1019 & 100 \\
LTA only & 194 & 25 \\
K18 only & 268 & 35 \\
LTA and K18 & 301 & 40 \\
Total & 763 & 100
\end{tabular}

Sections of the vallate papilla were stained for keratin 18 (MAb LE65), and with LTA or HPA. For LTA, 215 taste bud profiles (sections through taste buds) were examined for stained cells; for HPA, 291 profiles. positive boundaries around foliate taste buds. This replacement and the complete absence of BPA-positive, LTA-positive and HPA-positive cells suggests the disappearance from the foliate gustatory epithelium of both intragemmal and perigemmal cells. Not only was BPA staining reduced in the foliate papillae but it was also reduced in the adjacent ordinary epithelium (Fig. 6).

\section{Discussion}

In contrast to an increase in HPA staining with development, LTA staining was widespread at birth and decreased remarkably with development until only a subset of taste cells was reactive. Observations on hair follicles also indicate that the binding of lectins
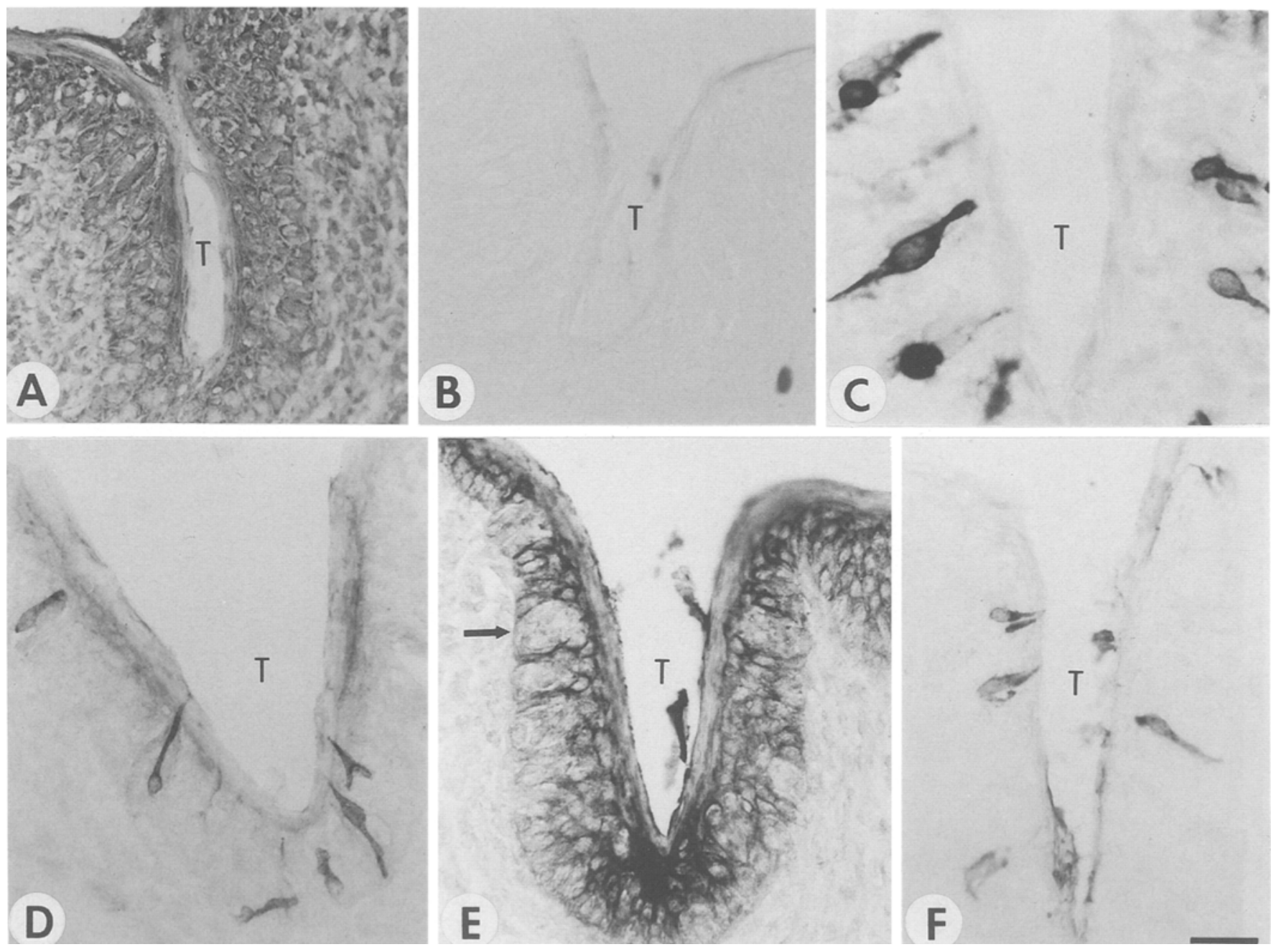

Fig. 5. Development of lectin binding in neonatal rat vallate papillae. In P3 vallate papilla: (A) LTA stained virtually all cells; whereas (B) BPA or HPA (not shown) stained none; while (C) MAb LE65 (keratin 18) stained several elongated taste cells. At P6: (D) LTA staining was restricted to several elongated taste cells, whereas (E) BPA stained all suprabasal cells, excluding intragemmal cells (arrow), while (F) HPA stained scattered elongated cells. $\mathrm{T}=$ vallate trench. The scale bar is 20 $\mu \mathrm{m}$ for (C) and $30 \mu \mathrm{m}$ for others. 
can increase or decrease during development (Ohno et al., 1990).

In adults two lectins gave widespread staining: UEA-I and BPA. UEA-I stained all suprabasal cells of the dorsum of rat tongue (Prime et al., 1985), including perigemmal cells in fungiform papillae. BPA also stained perigemmal cells but not intragemmal cells. Denervation eliminated perigemmal cell staining with UEA-I or with BPA. This suggests a nerve-dependency of perigemmal cells like the well-established nerve-dependency of intragemmal cells. Since denervation also reduced the BPA staining in the epithelium near the foliate papilla, even ordinary lingual epithelium may be somewhat nerve-dependent. BPA displayed two additional noteworthy features. First, all BPA-negative cells appeared to contact the basal lamina. Secondly, because the BPA-positive boundaries, which laterally surround adult vallate taste buds, developed after the taste buds formed, the boundaries are probably a consequence rather than a determinant of taste bud position and size.

$\alpha$-L-Fucose is an inhibitory sugar for both UEA-I and LTA binding. The contrast in adults between the widespread UEA-I staining and the restriction of LTA staining to a subset of intragemmal cells probably reflects differences in specific oligosaccharide binding requirements (Menghi et al., 1989). Similarly, while DBA, SBA and HPA are all inhibited by $\alpha-N-$ acetylgalactosamine (GalNAc), the widespread staining with DBA and SBA and the restriction of HPA
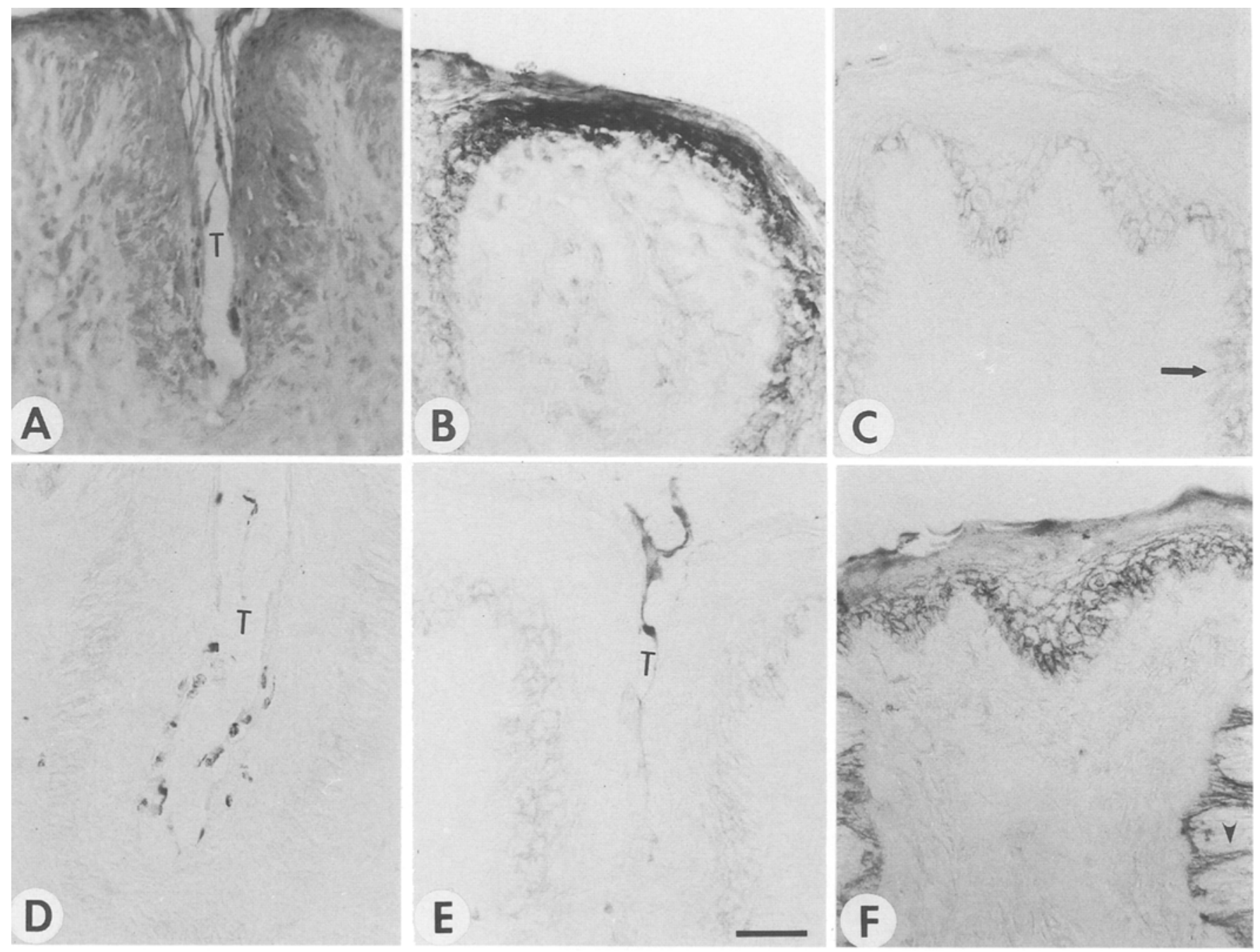

Fig. 6. (A) Denervation eliminated taste cells and LTA binding in adult foliate papillae. The photograph was overexposed to reveal the outlines of cells. (B) Denervation eliminated taste cells and BPA-reactive perigemmal cells in fungiform papillae. (C) Denervation reduced the intensity of BPA staining in the lingual epithelium adjacent to the foliate papillae. The arrow indicates the reduced staining in the margin of a foliate trench. The denervated foliate gustatory epithelium lacked staining with: (D) HPA (cellular debris is also evident) and (E) BPA. (F) In the innervated contralateral portion of the section shown in (C), BPA staining remained intense in both the foliate papillae and the ordinary epithelium. The arrowhead shows BPA-positive boundaries between foliate taste buds. The tissue was collected 15 days postoperatively for panel (B) and 21 days postoperatively for the remaining panels. Scale bar in (E) is $40 \mu \mathrm{m}$ for (C) and (F) and $35 \mu \mathrm{m}$ for the others. 
staining to intragemmal cells suggest that HPA has more specific carbohydrate binding requirements.

Our recent studies have revealed five keratins in taste buds (keratins 7, 8, 18, 19 and 20; Wong et al., 1994; Knapp et al., 1995; Zhang et al., 1995). All except keratin 18 are present in most, probably all, vallate intragemmal taste cells. Twenty-six per cent of the intragemmal cells are keratin 18-positive; these cells are a subset of older intragemmal cells (Zhang et al., 1995). LTA and HPA also reacted selectively with subsets of vallate taste cells. Here we indicate three plausible sites of HPA binding to keratin 18positive cells.

1. HPA may bind to a GalNAc glycoconjugate on the surface of the keratin 18-positive cells.

2. HPA may bind to GalNAc glycoconjugates on keratin 18 itself. Ultrastructural analysis of human sweat gland cells indicates keratin glycosylation; UEA-I bound to keratin filaments and to the cell surface (Metzler et al., 1990). In biochemical studies radiolabelled sugars glycosylated keratin 18 (King \& Hounsell, 1989; Chou et al., 1992). The normal O-linked GlcNAc glycosylation of keratin 18 fluctuated with the cell cycle (Chou \& Omary, 1993).

3. Rather than binding to GalNAc glycoconjugates, HPA may have bound to a peptide sequence in keratin 18. Concanavalin A binds a hexapeptide no less well than the blocking sugar methyl $\alpha$-D-mannopyranoside (Scott et al., 1992). Shikhman et al. (1994) demonstrated that six lectins which bind $\mathrm{N}$ acetylglucosamine also react with a decapeptide sequence in keratin 14 . (Keratin 14 in rat tongue is mainly restricted to basal cell keratinocytes.) They further demonstrated that anti-GlcNAc monoclonal antibodies reacted with the same decapeptide. In addition, the decapeptide could act as an antigen to produce an anti-GlcNAc immune response.

While keratin 18 has not been examined for peptides that might bind with lectins, our results bear on this possibility in taste cells. Intragemmal cells double stained for BrdU and HPA are first observed about 3 days after BrdU injection. Intragemmal cells double stained for BrdU and keratin 18 are also first observed about 3 days after BrdU injection (Zhang et al., 1995). A reasonable estimate for the age of cells first co-displaying keratin 18 synthesis and HPA binding is $3 \pm 0.5$ days. During turnover of vallate cells, cell division is restricted to the basal layer and the neighbouring cell layer (Zhang et al., 1995). Within 1 day BrdU-positive cells enter the taste bud where they do not divide (Zhang et al., 1995).

Whereas most stained cells were double stained (685) the presence of cells that were positive only for keratin 18 (130) and others that were positive only for
HPA binding (204) is consistent with the existence of a subset of cells that lacks an obligatory linkage between keratin 18 synthesis and HPA binding. A given cell may synthesize keratin 18 before binding HPA, or vice versa. The presence of 204 HPA-positive/keratin 18-negative cells indicates that keratin 18 is not required for HPA binding. The presence of 130 keratin 18-positive/HPA-negative cells argues against constitutive binding of HPA to keratin peptides. Consequently, the binding of HPA to the surface of cells that are, or shortly will be, keratin 18-positive is likely to be the predominant mode of HPA binding.

The number of mammalian intragemmal cell subtypes has not been established. Some morphological classifications are: dark, intermediate and light; or type I, II and III cells (Murray, 1973; Delay et al., 1986; reviewed in Roper, 1989). The keratin 18-positive/HPA-positive intragemmal cells described here are too uncommon and too old to represent all dark cells. They could be a combination of intermediate and light cells or a combination of type II and III cells. In rabbit taste buds HPA binds preferentially to type III intragemmal cells (Witt and Miller, 1992).

It may be useful to characterize patterns of cell glycosylation to distinguish subtypes among morphologically similar cells. For example, although olfactory chemosensory receptor cells are morphologically indistinguishable, they have been found to consist of several subtypes based upon lectin binding and carbohydrate epitopes (reviewed in Mori, 1993). Similarly, the application of lectin and antibody histochemical technologies may elucidate additional classes of taste receptor cells. With both taste and olfactory receptor cells, glycosylation may play several crucial roles, such as specifying aspects of synaptic connections.

\section{Acknowledgements}

We thank M. Cotter and C. Zhang for their assistance. This work was supported in part by Grant DC00083 from the National Institute on Deafness and Other Communication Disorders, National Institutes of Health. USPHS.

\section{References}

AKABAS, M. H., DODD, J. \& AL-AWQATI, Q. (1988) A bitter substance induces a rise in intracellular calcium in a subpopulation of rat taste cells. Science 242, $1047-50$.

BRABEC, R. K., PETERS, B. P., BERNSTEIN, I. A., GRAY, R. H. \& GOLDSTEIN, I. J. (1980) Differential lectin binding to cellular membranes in the epi- 
dermis of the newborn rat. Proc. Natl. Acad. Sci. USA 77, 477-9.

BROWN, R., KU, W. W. \& BERNSTEIN, I. A. (1987) Changes in lectin binding by differentiating cutaneous keratinocytes from the newborn rat. J. Invest. Dermatol. 88, 719-26.

CHOU, C. -F. \& OMARY, M. B. (1993) Mitotic arrest-associated enhancement of $O$-linked glycosylation and phosphorylation of human keratins 8 and 18. J. Biol. Chem. 268, 4465-72.

CHOU, C. -F., SMITH, A. J. \& OMARY, M. B. (1992) Characterization and dynamics of O-linked glycosylation of human cytokeratin 8 and 18. J. Biol. Chem. 267, 3901-6.

DELAY, R. J., KINNAMON, J. C. \& ROPER, S. D. (1986) Ultrastructure of mouse vallate taste buds: II. Cell types and cell lineage. J. Comp. Neurol. 253, 242-52.

DODD, J. \& JESSELL T. M. (1985) Lactoseries carbohydrates specify subsets of dorsal root ganglion neurons projecting to the superficial dorsal horn of rat spinal cord. J. Neurosci. 5, 3278-94.

Gargiulo, A. M., PEDini, V. \& CeCCARelli, P. (1993) Lectin histochemical study of bovine lingual glands. Arch. Oral Biol. 38, 881-4.

HOSLEY, M. A. \& OAKLEY, B. (1987) Development of the vallate papilla and taste buds in rats. Anat. Rec. 218, 216-22.

KING, I. A. \& HOUNSELL, E. F. (1989) Cytokeratin 13 contains O-glycosidically linked $N$-acetylglucosamine residues. J. Biol. Chem. 264, 14022-8.

KNAPP, L., LAWTON, A., OAKLEY, B., WONG. L. \& ZHANG, C. (1995) Keratins as markers of differentiated taste cells. Differentiation, 58, 341-9.

MENGHI, G., SCOCCO, P., ACCILI, D., BONDI, A. M. \& MATERAZZI, G. (1989) Attempt to visualize an endogenous lectin recognizing alpha-L-fucose immunohistochemistry in the rabbit oviduct. Acta Histochem. 87, 115-21.

METZLER，G., SCHAUMBURG - LEVER，G. \& LIEBIG，K. (1990) Ultrastructural localization of keratin and alpha-L-fucose in human eccrine seat glands. Arch. Dermato. Res. Archiv. für Dermatolog. Forsch., 282, 12-16.

MORI, K. (1993) Molecular and cellular properties of mammalian primary olfactory axons. Micros. Res. Tech. 24, 131-41.

MURRAY, R. G. (1973) The ultrastructure of taste buds. In The Ultrastructure of Sensory Organs (edited by FRIEDEMANN， I.), pp. 1-81. Amsterdam: North Holland.

NEOGRADY S., GALFI, P., VERESEGYHAZY, T., BARDOCZ, s. \& PUSZTAI, A. (1994) Lectins as markers of rumen epithelial cell differentiation. Histochem. J. 26, 197-206

OHMURA, s., HORIMOTO, s. \& FUJITA, K. (1989) Lectin cytochemistry of the dark granules in the type I cells of Syrian hamster circumvallate taste buds. Arch. Oral Biol. 34, 161-6.

OHNo, J., FUKUYAMA, K. \& EPSTEIN W.L. (1990). Gly- coconjugate expression of cells of human anagen hair follicles during keratinization. Anat. Rec. 228, 1-6.

PRIME, S. S., ROSSER, T. J., MERA, S. L., MALAMOS, D., MAITLAND, N. J. \& SCULly C. (1985) Preferential lectin binding to specific layers of rat oral epithelium and modification by enzyme pretreatment. J. Invest. Derm. 85, 531-4.

ROPER, S. D. (1989) The cell biology of vertebrate taste receptors. Ann. Rev. Neurosci. 12, 329-54.

SCOTT, J. K., LOGANATHAN, D., EASLEY, R. B., GONG, X. \& GOLDSTEIN, I. J. (1992) A family of concanavalin A-binding peptides from a hexapeptide epitope library. Proc. Natl Acad. Sci. USA 89, 5398-402.

SHIKHMAN, A. R., GREENSPAN, N. S. \& CUNNINGHAM, M. w. (1994) Cytokeratin peptide SFGSGFGGGY mimics $N$-acetyl- $\beta$-D-glucosamine in reaction with antibodies and lectins, and induces in vivo anti-carbohydrate antibody response. J. Immunology 153, 5593-606.

SHIMIZU, T., NETTESHEIM, P., MAHLER, J. F. \& RANDELL, S. H. (1991) Cell type-specific lectin staining of the tracheobronchial epithelium of the rat: quantitative studies with Griffonia simplicifolia I isolectin B4. J. Histochem. Cytochem. 39, 7-14.

SMITH, D. V., AKESON, R. A. \& SHIPLEY, M. T. (1993) NCAM expression by subsets of taste cells is dependent upon innervation. J. Comp. Neurol. 336, 493-506.

SMITH, D. V., KLEVITSKY, R., AKESON, R. A. \& SHIPLEY, M. T. (1994) Taste bud expression of human blood group antigens. J. Comp. Neurol. 343, 130-142.

SUTER, M. M., AUguSTIN-voss, H. G., PANTANO, D. M., FLANDERS, J. A. \& VARVAYANIS, M. (1991) Differentiation-dependent expression of lectin binding sites on normal and neoplastic keratinocytes in vivo and in vitro. J. Histochem. Cytochem. 39, 1101-12.

TAKAMI, S., GETCHELL, M. L. \& GETCHELL, T. V. (1994) Lectin histochemical localization of galactose, $\mathrm{N}$-acetylgalactosamine, and $\mathrm{N}$-acetylglucosamine in glycoconjugates of the rat vomeronasal organ, with comparison to the olfactory and septal mucosae. Cell Tissue Res. 277, 211-30.

WITT, M. \& MILLER, I. J. JR (1992) Comparative lectin histochemistry on taste buds in foliate, circumvallate and fungiform papillae of the rabbit tongue. Histochem. 98, 173-82.

WITT, M. \& REUTTER, K. (1988) Lectin histochemistry on mucous substances of the taste buds and adjacent epithelia of different vertebrates. Histochem. 88, $453-61$.

WONG, L., OAKLEY, B., LAWTON, A. \& SHIBA, Y. (1994) Keratin 19-like immunoreactivity in receptor cells of mammalian taste buds. Chem. Senses 19, 251-64.

ZHANG, C., COTTER, M., LAWTON, A., OAKLEY, B., WONG, L. \& ZENG, Q. (1995) Keratin 18 is associated with a subset of older taste cells in the rat. Differentiation, in press. 